Jurnal Akuntansi dan Investasi, Vol. 19 No. 1, Hlm: 1-11 Januari 2018

Artikel ini tersedia di website: http://journal.umy.ac.id/index.php/ai

DOI: $10.18196 /$ jai.190187

\title{
Indonesian Local Government's Accountability and Performance: The Isomorphism Institutional Perspective
}

\author{
Muhammad Ahyaruddin ${ }^{1 *}$ and Rusdi Akbar ${ }^{2}$ \\ Faculty of Economics and Business Universitas Muhammadiyah Riau, Riau, Indonesia \\ Faculty of Economics and Business Universitas Gadjah Mada, Yogyakarta, Indonesia \\ ARTICLE INFO \\ Article history: \\ received 11 Jul 2017 \\ reviewed 27 Aug 2017 \\ revised 12 Oct 2017 \\ accepted 12 Oct 2017 \\ Keywords: \\ Accountability; \\ Performance; \\ Institutional \\ Isomorphism

\begin{abstract}
A B S TRACT
This research aims to explore the accountability and performance of government agency in perspective of institutional theory. It analytically answer two research questions: Do institutional isomorphism exist in the implementation of performance Do government agencies actually use performance measurement information to aid decision-making and help plan for future performance improvement? $\left(\mathrm{RQ}_{2}\right)$. This study is a qualitative research to answer two research question proposed with use semi-stuctured and open interview from SKPD officers in the local government of Yogyakarta Province. The results of interview were analyzed use thematic content analysis. Our finding show that three form of institutional isomorphism (coersive, mimetic and normative) were existed in the implementation of performance measurement system and accountability in public sector organizations. This result also show an interesting finding in government agency that performance information who reported in LAKIP was only a formality. The information content in LAKIP is not used as feedback to aid decision-making and plan for future performance improvement.
\end{abstract} \\ measurement system and accountability in public sector organizations? $\left(\mathrm{RQ}_{1}\right)$ and
}

(C)2018 JAI. All rights reserved

\section{INTRODUCTION}

Since the reformation era in 1998/1999, the governance in Indonesia has slowly started to change into the application of New Public Management (NPM) concept. This NPM concept is seen as one of the concepts that can improve public sector efficiency, improve public institutions' responses to society, and is expected to increase the government accountability and performance (Christensen and Laegreid, 2014) and therefore at the beginning of the reform, the government issued presidential instruction number 7 year 1999 on the Government Institution Performance Accountability Report (LAKIP) as a form of government commitment in supporting bureaucracy reform and reform in the field of financial management. LAKIP is one of the government accountability to the public that

\footnotetext{
${ }^{1}$ This research is funded by In Search of Balance (ISB) Batch III 2015 program, Cooperation between Gadjah Mada University and Agder University, Norway.
}

contains information about the success of the program and activities.

One form of the derivation of the government institutions to make LAKIP is the need for a good performance measurement system and adequate. This performance measurement system should be implemented systematically and continuously to create optimal, clean, and responsible organizational management. When these performance measurement systems are well-executed, the government will be easier in doing the efficiency and effectiveness of public services, as well as resource allocation and decision-making that can ultimately improve accountability and organizational performance (Akbar et al., 2012, Christensen and Laegreid, 2014).

However, Nurkhamid (2008) states that the reality that has been happening in the government agencies is that accountability and performance generated are still false and tend to be biased and often questioned. Government agencies have a tendency to report good performance excessively, while failed programs tend to be hidden (Nurkhamid, 2008). Performance reports that 
have been made by the government agencies are merely to meet the regulatory and policy requirements obligations. They do not substantively reflect the performance that occurs in the field. This could mislead the public as an information user and finally results excessive public expectations towards government agencies (Ahyaruddin and Akbar, 2016).

Based on the concepts in institutional theory, Ashworth et al. (2009) states that the main reason behind organizational change is simply to gain legitimacy rather than substantively improving performance. This is also reinforced by the findings of several studies which state that the organization will be faced with competition to gain institutional legitimacy and political power, as well as community and customer support (Chenhall, 2003; Akbar et al., 2012; Sofyani and Akbar, 2013 ; Wijaya and Akbar, 2013; Akbar et al., 2015; Ahyaruddin and Akbar, 2016).

Performance measurements and improvements in the government organizations need to be viewed more thoroughly and comprehensively. The amount of demands for transparent management of government organizations is not necessarily accompanied by government efforts to improve performance and accountability in the field. It may be that performance reporting and accountability are only a matter of formality and therefore the existence of a clear measuring instrument is very important for government organizations. Currently, one of the indicators of government performance accountability measurement is LAKIP (Permendagri number 34 of 2011). LAKIP was originally created as an annual performance report that requires government agencies to provide an overview of mission, vision, strategic objectives, and key performance indicators and provide mechanisms for linking key performance indicators to goals and organization budgets (Rhodes et al., 2012). However, LAKIP is currently one of the assessment criteria of successful local government performance by the central government. LAKIP is intended to help the government achieve accountability, as it requires system and performance information that are more comparable, relevant, and useful in governmental decision-making (Akbar et al., 2015).

Research related to the accountability and performance of local government has been done for several times, for example Nurkhamid (2008); Akbar et al. (2012); Sofyani and Akbar (2013); Manafe and Akbar (2014). However, these researches focused more on hypothesis testing using quantitative method approach and therefore it cannot describe and explain in more detail the accountability condition and real performance in the field.

Overall, this paper begins with a brief explanation of the problem and the research context that is described in the introduction. After that, it is followed by an explanation of the theoretical framework used, research methods, and interview results. The final section of this paper explains the conclusions, implications, and suggestions for further research.

\section{LITERATURE REVIEW AND FOCUS OF STUDY}

\section{Institutional Theory}

In the organization context, especially public sector organizations, institutional theory becomes most references to explain the structure and changes of an organization. Moreover, those organizations have many interactions and are influenced by the external environment. Several researches that used institutional theory in the context of public sector organizations especially in Indonesia, for example: Akbar et al. (2012); Wijaya and Akbar (2013); Syachbrani and Akbar (2013); Sofyani and Akbar (2013); Manafe and Akbar (2014); Primarisanti and Akbar (2015); Sofyani and Akbar (2015); Akbar et al. (2015); and Ahyaruddin and Akbar (2016).

Institutional theory is a sociology theory that seeks to explain organizational structure (Scott, 1995). Institutional theory has many dimensions. In an organizational context, the concept of institution and institutionalization is defined in different ways. Scott (1987) defines institutionalization as:

\footnotetext{
"The social process by which individuals come to accept a shared definition of social reality a conception whose validity is seen as independent of the actor's own views or actions but is taken for granted as defining the "way things are and/or the way things are to be done".
}

The institutional theory explains a structure where an organization adopts something conformity with a cultural ethic code that then leads to the legitimacy and support of external organizations (DiMaggio and Powell, 1983; Ahyaruddin 
and Akbar, 2016). DiMaggio and Powell (1983) suggest that time over time, in an established area, organizations tend to move toward homogenyzation, although at first they show huge diversity. The exact term for describing the homogenization process is isomorphism.

DiMaggio and Powell (1983) distinguish two types of isomorphism, namely: competitive isomorphism and institutional isomorphism. Competitive isomorphism is related to efficiency (technical or economic explanation). When there is a cheaper, better, or more efficient way of doing things, competitive strength leads the organization toward that new approach. While institutional isomorphism is developing in accordance with three mechanisms, namely coercive, mimetic, and normative. Based on the concept of institutional isomorphism, institutional influences are dispersed through an organizational area called the organization's field, which means that organizations as a whole are a recognized area of institutional life, namely key suppliers, resources and product customers, regulatory dependencies, and other organizations that provide similar services and products (Erro and Sanchez, 2012). Structural isomorphism is described as an important consequence of the competitive and institutional processes. As a result, organizations do not compete to gain resources or customers but to gain power and legitimacy, in addition to social welfare and economic outcomes (DiMaggio and Powell, 1983; Erro and Sanchez, 2012; Akbar et al., 2012; Ahyaruddin and Akbar, 2016).

Meyer and Rowan (1977) as quoted by Akbar et al. (2012) stated that isomorphism has three consequences to the organization, (1) they link legitimated elements externally, not in efficiency, (2) they use external criteria or ceremonial to determine the value of the structural elements, and (3) reliance on external institutions keep reducing turbulence and maintaining stability.

\section{Accountability Concept}

Accountability has been described as one of the golden concepts and no one can oppose it (Iyoha and Oyerinde, 2010). Pollit (2003) as quoted by Iyoha and Oyerinde (2010) said that accountability "has become a good thing, which we seem unable to fulfill". As well as Bovens (2007) argues that accountability is increasingly being used in discourse politics and policy documents because it conveys an image of transparency and trust.
Roberts and Scapens (1985) as quoted by Sinclair (1995) state that accountability requires a relationship in which a person is asked to explain and take responsibility for their actions. Sinclair (1995) states that how that accountability defined depends on the ideology, motives and language of our time. Furthermore, Sinclair (1995) argues that accountability has a special meaning of discipline and can be defined from multiple perspectives. For example, an auditor discusses accountability as being related to financial or numerical issues, whereas political scientist views accountability as a political necessity and law students view it as a constitutional arrangement, while a philosopher sees accountability as part of ethics (Iyoha and Oyerinde 2010). According to Sinclair's (1995), the definition of accountability is divided into five forms of accountability: (1) political accountability, (2) public accountability, (3) managerial accountability, (4) professional accountability, and (5) personal accountability.

\section{Political Accountability}

The concept of political accountability comes from the democratic traditions of the Athenians and Westminster. In this concept, the officials of public organizations do authority on behalf of elected representatives, who in turn are directly responsible to the people (Day \& Klein, 1987 in Akbar, 2011). In a democratic government (e.g. Indonesia), the executive officially releases their accountability to politicians in parliament as representtatives of the people (Sinclair, 1995).

\section{Public Accountability}

Public accountability is almost similar to political accountability, but is more informal and this accountability is directly facing the public, the individual, or the community. Public accountability involves various mechanisms available to clarify organizational policies and activities such as public hearings, provision of government reports in the mass media, or even through real-time communication tools that enable people to communicate to government officials easily and directly (Sinclair, 1995; Akbar, 2011).

\section{Managerial Accountability}

Managerial accountability is seen to focus on controlling inputs and outputs or outcomes. In the concept of managerial accountability, accounta- 
bility relationships are also found within the organization itself. Managerial accountability in this case is related to the responsibility of lower officials to higher officials for the performance of delegated tasks (Akbar, 2011).

\section{Professional Accountability}

Professional accountability is related to the calling or sense of duty that a person has as a member of a professional or expert group, which then occupies a privileged and knowledgeable position in society (Sinclair, 1995). In this case, government employees and officials are required to act and behave professionally to provide the best service and they can provide benefits based on their skills and expertise (Akbar, 2011).

\section{Personal Accountability}

The concept of personal accountability is related to individual responsibility and the ultimate point of accountability. This accountability lies in the compliance of personal conscience as a logical consequence of the internalization of moral and ethical values, such as respecting human dignity, and acting by accepting responsibilities to influence the lives of others (Sinclair, 1995; Akbar, 2011).

The term of accountability can be defined differently ways and it changes over time. There is no single definition of accountability that is generally accepted by researchers. Many researchers define accountability according to their respective contexts and conditions. In the context of public sector organizations, Inaga (1991) as quoted by Iyoha and Oyerinde (2010) said that accountability requires the government to provide a reason related to the source and use of public resources. Therefore, accountability in this case is related to supervision and control of government behavior, prevent the development of power concentration, and improve the learning ability and effectiveness of public administration (Iyoha and Oyerinde, 2010). In the constitutional system of governance, there are two types of accountability: (1) internal accountability, which is a type of direct accountability that applies within a particular organizational system and involves direct reporting of subordinates to superiors, and (2) external accountability which is a type of indirect accountability that involves reporting to outside organizations (Matek, 1977 in Akbar, 2011).

\section{Performance Measurement and Isomorphism}

Several researches that adopt the theory of isomorphism assume that organizations which conducted competition is not only for resources and customers but also for political power and institutional legitimacy (Akbar et al., 2012). Institutional theory suggests that organizations pursue legitimacy by adjusting or matching to existing isomorphic pressures in their environment (Ashworth et al., 2009) and therefore in this case the theory is relevant to explain the performance measurement system as one of NPM concept which is expected to give benefit in increasing efficiency, accountability, and service quality of public sector organization (Ahyaruddin and Akbar, 2016).

Performance measurement system in public sector organizations, especially the government according to Pilcher and Dean (2009) might probably depend on the power relations between their constituents and the government itself. In Indonesia, normally, there are also power pressures from the central government on local governments in the decentralized governance systems. This happens usually through the enactment of laws and regulations. One example is Inpres number 7 year 1999 which requires all government agencies including local governments to report their performance to the central government. The existence of such coercive pressure is because most local governments in Indonesia have the dependence of financial resources and recognition through various systems of appreciation from the central government (Akbar et al., 2012; Ahyaruddin and Akbar, 2016).

This research tries to analyze and explore qualitatively what is happening is actually related to the accountability and performance of local government. This research focuses on the following two Research Questions (RQ):

$\mathrm{RQ}_{1}$ : Is institutional isomorphism occurring in the practice of applying performance measurement and accountability systems to public sector organizations?

$\mathrm{RQ}_{2}$ : Do government agencies use performance measurement system information to help the decision-making and plan for future performance? 


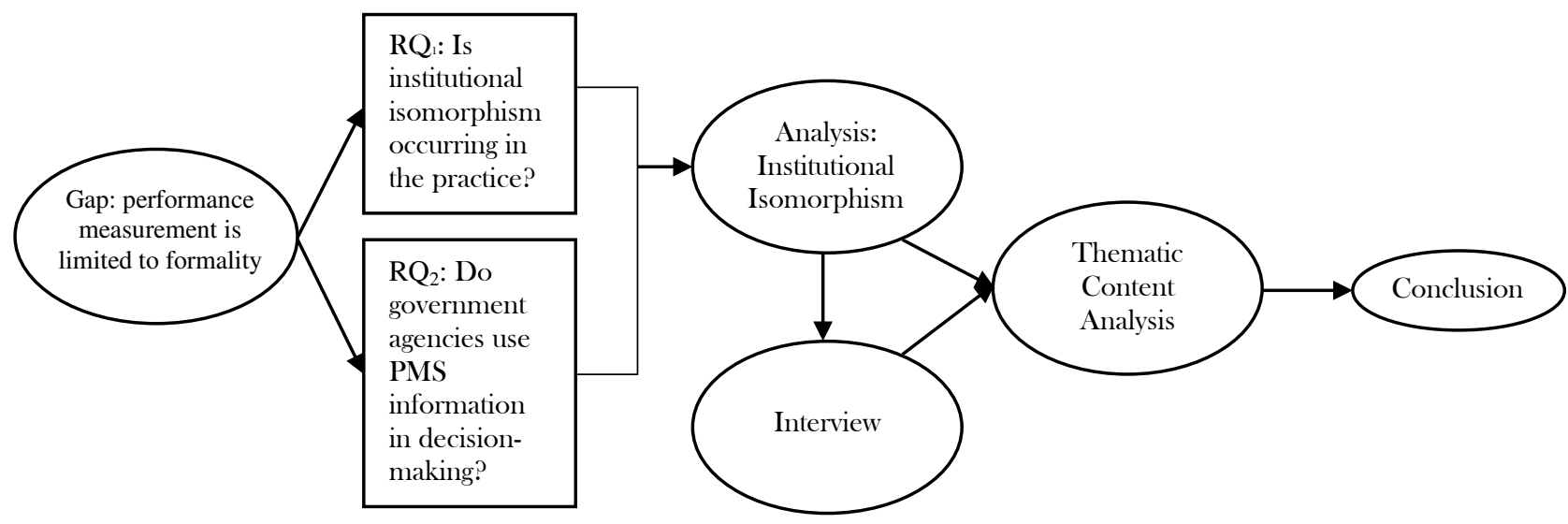

Figure 1: The Research Thinking Framework

\section{RESEARCH METHOD}

This research is a research development which the writer has done before with survey method. The result of preliminary research with mixed method using explanatory sequential design then further developed with qualitative method. The results reveal some important issues that need to be exploited deeper using detailed research questions ${ }^{2}$.

The research questions raised in this paper were answered using semi-structured and open interviews. These interviews were conducted to investigate and explore the respondents' answers or experiences related to important issues identified earlier, such as accountability, performance measurement, and institutional isomorphism (coercive, normative, and mimetic). The step taken to select the respondents who will be interviewed was with considering quantitative results, especially for cases of extreme data or outliers (Creswell and Clark, 2011) by using a scatter plot chart on Microsoft Excel 2010 software.

The interviews were conducted on December 24, 2014 to January 2, 2015 using semi-structured and open methods to senior SKPD officials. The result of scatter plot analysis shows that the selected interviewee is five people, consist of two people from Sleman regency, one from Yogyakarta city, and two from Bantul regency. The officials were senior officials from echelon III (two persons) and echelon IV (three persons) in various positions, such as: Secretary,

\footnotetext{
${ }^{2}$ The results of empirical studies can be seen in Ahyaruddin and Akbar's Research (2016)
}

Head of Manpower Division, Head of Planning and Reporting Section, Head of Sub-Division of Economic and Socio-Cultural Research and Development, as well as Head of Sub-Section of Analysis of Position and Apparatus. There were three men and two women involved in the interview. The length of the interview conducted was ranged between 20-30 minutes. In conducting the interview, the researcher recorded it using a digital voice recorder, then transcribed it into text form and if necessary then the researcher noted the special things as well as ideas that emerged from the transcript (Creswell and Clark, 2011; Primarisanti, 2013).

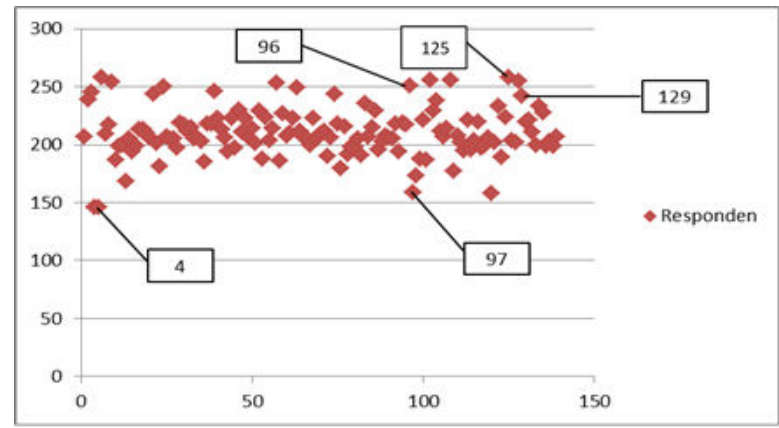

Figure 1. The Results of Scatter Plot of Respondents Data Distribution

Qualitative data from the interviews were analyzed by using thematic content analysis. This analysis is a research technique to describe the purpose, order, and extent of the actual content of a communication (Cooper and Schindler, 2006). The thematic content analysis can also be defined as a method for identifying, analyzing, and reporting patterns within a group of data (Braun and Clarke, 2006). 


\section{RESULT AND DISCUSSION}

\section{Institutional Isomorphism}

The main theme raised in this research is related to three dimensions of institutional isomorphism that are coercive, mimetic, and normative. In simple language, coercive isomorphism refers to the pressures the organization faces to change or take action; mimetic isomorphism refers to organizations that mimic other organizations because of uncertainty; and normative isomorphism refers to the norms or professional cognitive understanding. These three main themes become the reference in making a list of relevant questions to respondents to investigate the possible isomorphic pressures during the measurement and reporting process of performance and accountability practices in government agencies.

Table 1 shows the results of the process of preparing the performance reports of government agencies in accordance with the themes raised in this study. The majority of respondents (as much as $80 \%$ ) revealed that in the preparation of performance reports refer to regulation and legislation. However, this finding is very interesting because in fact not all agencies are guided by regulations. Some institutions (as much as 20\%) actually refer to other institutions that indicate imitation (mimetic isomorphism occurred) in preparing performance reports. While some other institutions also received help from outsiders, such as from BPKP, universities, local governments, and MenPAN RB.

Table 1. Field Findings from the Preparation Process of SKPD Performance Report

\begin{tabular}{|c|c|c|}
\hline $\begin{array}{c}\text { Preparing Performance } \\
\text { Reports }\end{array}$ & Theme & $\begin{array}{c}\text { Number of } \\
\text { Agencies } \\
\text { (\%) }\end{array}$ \\
\hline \multicolumn{3}{|l|}{ Mengacu pada: } \\
\hline $\begin{array}{l}\text { 1. Regulation and } \\
\text { Legislation }\end{array}$ & Coercive & $80 \%$ \\
\hline $\begin{array}{l}\text { 2. Report of Other } \\
\text { Agencies }\end{array}$ & Mimetic & $20 \%$ \\
\hline \multicolumn{3}{|l|}{ Dibantu oleh: } \\
\hline 1. BPKP & Normative & $20 \%$ \\
\hline 2. University & Normative & $20 \%$ \\
\hline $\begin{array}{l}\text { 3. Independent } \\
\text { Consultant }\end{array}$ & Normative & - \\
\hline $\begin{array}{l}\text { 4. Local } \\
\text { Government }\end{array}$ & Normative & $40 \%$ \\
\hline 5. MenPAN RB & Normative & $20 \%$ \\
\hline
\end{tabular}

The results of thematic content analysis based on the evidence that were obtained from interview with the respondent to answer this research question about institutional isomorphism are explained in more detail below:

\section{Coercive Isomorphism}

The strong institutional isomorphism influencing government agencies is coercive isomorphism. This pressure comes from political influence and legitimacy issues, whether done in the form of formal or informal pressures from other organizations. One of the most obvious forms of this coercive pressure is regulation and rules. Constitutional government system that is decentralized like in Indonesia is very possible and very normal to have pressure of power from the central government against local governments and on similar organizations under it, for example government institutions, agencies, SKPD, and others (Ahyaruddin and Akbar, 2016). One example of this coercive pressure is the regulation is issued by the government, e.g. Presidential Instruction No. 7 year 1999 which requires all government agencies including local governments to report on their performance to the central government.

The existence of such coercive pressure is because most of local governments in Indonesia have the dependence of financial resources and require an acknowledgment through various systems of appreciation from the central government (Akbar et al., 2012). Brignall and Modell (2000) in their research also revealed that regulation and rules is a legislative mandate that become one of the factors that is relevant to the successful implementation of reforms in government organizations. Not only in Indonesia but the same condition also occurs in public institutions in the UK. Public managers in the UK consider that regulation and law are one of the main factors of change (Talbot, 2008). This is in accordance with the answers given by the respondents in this study:

\footnotetext{
“Our management's work is always based on the regulations, it is the main basis we work, so if it is associated with the rules concerning performance improvement, it is obviously very close, very supportive, because it becomes part, well, like our signs in working, because our position is now clear that it must be determined in accordance with-if in the financial term, it is called DPA (budget execution
} 
document), that is the key, that is the term of our work contract. So that the relation to the rules that is concerning the performance improvement is clearly very impact.” (R127, Secretary of the District).

"It is very important. Without "Perda" (local regulations) we should not implement it." (R125, Head of Manpower Division).

"Well actually, that regulation provides us the actors of the governance process. It provides the roadmap in fact, the rules. So for example, there are three things on how the instructions about the use of money, e.g. relating to money, for example there is the procurement of goods and services, financial administration, and then service management. All these three things are giving the roadmap actors, how it must be done step by step. It gives us certainty. So psychologically, we have an irrefutable foundation in the form of regulation. With such indisputable certaintymeaning in the process, there are usually problems (for example, including conflicts of interest, then intervention from superiors), it is because we already have the rules, it gives us a psychological sense of security to do that and therefore because there is no hesitation, the automatic level of efficiency of its implementation will be faster in time, then its output can be more assured." (R4, Head of Economic Social \& Culture R \& D sub-sector).

"Obviously it gives impact, because without the regulations, we cannot run in accordance with the expected rail, so we still run the performance in accordance with existing regulations, it is our signs to step that we have a protection, the regulation, as legal protection." (R96, Head of Planning and Reporting).

The answers given by the respondents above are clear that coercive isomorphism occurs in the practice of applying the performance measurement and accountability in public sector organizations (government agencies) in Indonesia. The existence of great autonomy for the region to determine its own fate cannot be completely separated from the central government. This is because most local governments in Indonesia have dependence on central government in the form of financial resources and through reward system (Akbar et al., 2012). There is no other option for the region nor the institutions below other than to obey the rules and report its performance in order to continue receiving funding through the budget allocation process from the central government.

\section{Mimetic Isomorphism}

Furthermore, the institutional isomorphism that can affect the accountability and performance of government agencies is mimetic isomorphism. DiMaggio and Powell (1983) revealed that mimetic isomorphism arises as a result of the process to respond to the environmental uncertainty in the area in which the organization operates. When an organization has low technology, the organizational goals are unclear and highly ambiguous, or even the organizational environment creates symbolic uncertainty and therefore it may pose itself in the shape of other organizations in order to gain legitimacy (DiMaggio and Powell, 1983). The existence of organizational tendencies to imitate other organizations is causing similarities and even resemblance that many organizations become homogeneous.

In addition, the current reformation era created many new regulations from the central government that could have an impact on overlapping or even contradictory rules between local governments. This can then lead to confusion for the government (officials) to implement the rules (Ahyaruddin and Akbar, 2016). This condition is then exacerbated again with the form or format of the reports that are still unclear at the level of SKPD to be used in making performance reports. This is one of the strong reasons for SKPD to imitate or refer to the report format at other agencies. So, what happened is they follow or imitate other organizations in making performance reports.

"In making the performance reports, we refer to Pemda (Local Goverment), and there is a coordination between agencies and it is coordinated by Bappeda.” (R125, Kabid Labor).

"So far, the report format at the SKPD level has not been very clear. It is necessary to develop templates for SKPD level.” (R96, Head of Planning and Reporting).

\section{Normative Isomorphism}

Normative isomorphism generally deals with professionalism and a way of formal and informal collaboration that can lead to organizational homogenisation. The professionalism that emerges in the context of this isomorphism comes from formal education and the expansion of professional networks that is undertaken by the organi- 
zation. Professional groups will gradually share collective norms and expectations about what behavior is desired by regulation or rules (DiMaggio and Powell, 1983).

Normative pressure in the context of public sector organizations usually comes from professsional groups such as consultants or universities through conferences, seminars, workshops, training, and mentoring. The role of this professional group becomes very crucial to the organization in order to reduce errors and to increase the chances of successful performance reporting practice and accountability (Akbar et al., 2012; Han and Koo, 2010). The professional institutions that usually play a role in assisting government agencies are the BPKP (Badan Pengawasan Keuangan dan Pembangunan, BPKP). In addition, there are universities which in this case become consultants in the process of program planning. The reason is simple, government agencies in Indonesia currently do not have enough resources and therefore to get optimal results in carrying out its activities, they hold the university because it is considered to have knowledge and excellent academic qualifications that hopefully can help the practice of organizational management in government agencies.

"Yes there is, with BPKP and directly from MENPAN (Ministry of Administrative Reform, Red). Assistance given is such as assistances, and then workshop. They gave the theories, and then the participants would directly practice. Usually, it is done once a year during the start of preparing the report; the coordinator will later request the members of the team, so those members who will be given training on LAKIP (R97, Head of Subdivision Job Analysis and Apparatus).”

"If we are going to have some kind of final evaluation at SKPD level, we will ask for feedback from each field and section for material preparation and performance evaluation for one year, such as workshop (R96, Head of Planning and Reporting).”

"The planning is called Sleman district manpower planning, the consultant is from Gadjah Mada University. Not only that, Sleman became the pilot project of SMART City, the city which its development is ITbased, its mentor is from ITB. In Indonesia there are seven cities that become pilot project. The one that handle it is Bappeda, we become part of it because we do the IT, like service of AK 1 card (kartu kuning), our service have ISO 9001 2008.” (R125, Head of Labor).

Thus, it is clear that public sector organizations, in this case government agencies, received huge benefit from professional groups such as BPKP or universities in performance measurement and organizational accountability practices. Therefore, this condition reinforces the evidence that normative isomorphism also occurs in the process by which the organization tries to obtain the best practice in its organizational management. The evidence of normative isomorphism in reporting the performance of government agencies has also been revealed in a study conducted by Akbar et al. (2012).

Related to the second research question $\left(\mathrm{RQ}_{2}\right)$ which is: "Do government agencies use performance measurement system information to help the decision-making and plan for future performance?" The results obtained were very surprising. The respondents who were interviewed in this research revealed that the performance measurement system information presented in LAKIP is not used in the decision-making process nor used to plan future performance.

\footnotetext{
"The serious thing has never happened (using the information contained in the LAKIP), which happened was only a formality. So LAKIP must be delivered on time, according to the format, accordingly, this way, delivered to DEPDAGRI (Ministry of Home Affairs, Red), to BAPPENAS (National Development Planning Agency, Red), but in fact it has only been delivered, the information is not used for anything. If for example, the performance of Minimum Service Standards (SPM) should be that much, that has meaning, sometimes not. For example, we have the data from year to year, the percentage of unlicensed homes, since the licensing service is there, it is not decreasing but is increasing. It means that the material, the data, the report, is not used by the government for taking the action, it should have clear action." (R4, Head of SocioEconomic and Economic Research Subdivision).
}

Based on the respondent's answers above, it is revealed that the performance accountability report submitted by government agencies is a form of formalities only to implement the regulatory obligations. The information contained does not become a specific goal that is designed to improve the performance and achievement of 
organizational outcomes. Whereas, normally, performance information that is reported by an agency should become a consideration in the decision making.

\section{CONCLUSION}

Based on the explanation, it can be concluded that accountability and performance practices that occur in government organizations are driven by isomorphic pressures that exist in their environment. In general, in order to improve accountability and performance of public services, government agencies in Indonesia will be affected by institutional isomorphism, in the form of coercive isomorphism, mimetic isomorphism, and normative isomorphism. This is because the organization (government agency) seeks to gain legitimacy and political support from both the community and other organizations (House of Representatives/Parliament, Mass Organizations, Non-Governmental Organizations, etc.).

This research also reveals interesting findings on government agencies. LAKIP which has been said by government agencies is only limited to the formalities to carry out the work obligations. The information contained is not used as a feedback for decision making or future performance improvement. It can be concluded that the performance that has been submitted is indeed pseudo because only limited to fulfil the obligation of regulation. This finding reinforces previous research that coercive pressure is very dominant in government organizations.

Decentralized governance systems such as in Indonesia normally have power pressures from the central government on local governments. This happens usually through the enactment of laws and regulations. One example is Inpres number 7 year 1999 which requires all government agencies including local governments to report their performance to the central government. These laws and regulations are a form of coercive isomorphism that is considered to be one of the successful aspects of reform implementtation in government organizations in Indonesia. While the form of mimetic isomorphism is by imitating other organizations in order to reduce the uncertainty and risk of failure. This mimetic isomorphism is done by looking at or referring to other agencies in preparing performance reports in an attempt to meet regulatory requirements. In addition, in order to reduce errors and increase the chances of successful performance reporting and accountability practices, government organizations are collaborating with professional groups such as BPKP and universities. This practice is one of the forms of normative isomorphism in which government organizations seek to gain the best practice in organizational management through the help of professional groups.

Theoretically, one of the important contributions in this research is that institutional isomorphism as one part of institutional theory is recognized as a basic framework that is able to explain the practice of performance measurement and accountability systems implementation in the public sector. The three components of institutional isomorphism (coercive, mimetic, and normative) become the evidence that have been confirmed by the organizations as influential factors in performance reporting and accountability practices. These findings broaden the results of the previous research and add the literature in the field of public sector management accounting. These findings also provide a strong belief in institutional theory that is suitable to be used in the context of government agencies in Indonesia.

However, this research has some limitations. First, the selection of informants in this research is based only on the outlier data distribution and therefore the number of respondents obtained is limited. The further research is suggested to select informants from both data distribution, whether from normal data distribution or outlier data distribution, so that there is representation from each of them and can increase the number of informants. Second, the length of the interview is limited due to informants' working time and therefore the information could not be explored deeper. The further research could choose the right time in order to obtain more information from the informants.

\section{ACKNOWLEDGMENT}

The author would like to thank the Board of ISB (In Search of Balance) who has provided financial support in this research as well as to the respondents who are willing to become informants so that this research could be completed properly. In addition, the author appreciated the anonymous reviewers who have provided input, suggestion, and critique of this research so that this paper can be further refined. 


\section{REFERENCES}

Ahyaruddin, M. and R. Akbar. 2016. The Relationship Between the Use of A Performance Measurement System, Organizational Factors, Accountability, And the Performance of Public Sector Organizations. Journal of Indonesian Economy and Business, 31 (1), 1 -22.

Akbar, R. 2011. Performance Measurement and Accountability in Indonesian Local Government. Ph.D dissertation, Curtin University.

Akbar, R., R. A. Pilcher, and B. Perrin. 2015. Implementing Performance Measurement Systems. Qualitative Research in Accounting \& Management, 12 (1), 3 - 33

Akbar, R., R. A. Pilcher, and B. Perrin. 2012. Performance Measurement in Indonesia: The Case of Local Government. Pacific Accounting Review, 24 (3), 262-291.

Ashworth, R., G. Boyne and R. Delbridge. 2009. Escape From the Iron Cage? Organizational Change and Isomorphic Pressures in the Public Sector. Journal of Public Administration Research and Theory, 19 (1), 165-87.

Bovens, M. 2007. Analyzing and Assessing Public Accountability. A Conceptual Framework. European Law Journal, 13 (4), 837-868.

Brignall, S. and S. Modell. 2000. An Institutional Perspective on Peformance Measurement and Management in the New Public Sector. Management Accounting Research, 11, 281-306.

Chenhall, R. H. 2003. Management control systems design within its organizational context: findings from contingency-based research and directions for the future, Accounting, Organizations and Society, 28, (2-3), 127-168.

Christensen, T. and P. Laegreid. 2014. Performance and Accountability - A Theoretical Discussion and An Empirical Assessment. Public Organization Review, 15 (2), 207-225.

Cooper, D. R. and P. S. Schindler. 2006. Business Research Methods (9th Ed.). New York: McGraw-Hill.

Creswell, J. W. and V. L. P. Clark. 2011. Designing and Conducting Mixed Methods Research (2nd Ed.). USA: Sage Publication.

DiMaggio, P. J. and W. W. Powell. 1983. The Iron Cage Revisited: Institutional
Isomorphism and Collective Rationality in Organizational Fields. American Sociological Review, 48, 147-160.

Erro, A. G. and J. A. C. Sanchez. 2012. Joining the UN Global Compact in Spain: An Institutional Approach. Revista de Contabilidad - Spanish Accounting Review (RC-SAR), 15 (2), 287-355.

Han, J. and J. Koo. 2010. Institutional Isomorphism and Decoupling among Korean Firms: Adoption of Performance Compensation System. Korean Journal of Sociology, 44 (3), 27-44.

Instruksi Presiden Republik Indonesia Nomor 7 Tahun 1999 Tentang Akuntabilitas Kinerja Instansi Pemerintah.

Iyoha, F.O. and D. Oyerinde. 2010. Accounting Infrastructure and Accountability in Management of Public Expenditure in Developing Countries: A Focus on Nigeria. Critical Perspective on Accounting, 21, 361373.

Manafe, M. W. N. and R. Akbar. 2014. Accountability and Performance: Evidence from Local Government. Journal of Indonesian Economy and Business, 29 (1), $56-73$.

Nurkhamid, M. 2008. Implementasi Inovasi Sistem Pengukuran Kinerja Instansi Pemerintah. Jurnal Akuntansi Pemerintah, 3 (1), 45-76.

Peraturan Menteri Dalam Negeri Nomor 34 Tahun 2011 Tentang Pedoman Evaluasi Laporan Akuntabilitas Kinerja Instansi Pemerintah di Lingkungan Kementerian Dalam Negeri.

Pilcher, R. A. and G. Dean. 2009. Consequences and Costs of Financial Reporting Compliance for Local Government. European Accounting Review, 18 (4), 72544.

Primarisanti, H. and R. Akbar. 2015. Factors Influencing the Success of Performance Measurement: Evidence form Local Government. Journal of Indonesian Economy and Business, 30 (1), 56 -71.

Rhodes, M., L. Biondi, R. Gomes, A. Melo, F. Ohemeng, G. Perez-Lopez, A. Rossi, and W. Sutiyono. 2012. Current state of public sector performance management in seven selected countries. International Journal of Productivity and Performance Management, 61 (3), 235-271. 
Scott, W. R., 1987. The Adolescene of Intritutional Theory. Administrative Science Quarterly, 32 (4), 493-511.

Scott, W. R., 1995. Institutions and Organizations. Thousand Oaks, CA: Sage.

Sinclair, A. 1995. The Chameleon of Accountability: Forms and Discourses. Accounting, Organizations and Society, 20 (2/3), 219237

Sofyani, H. and R. Akbar. 2015. Hubungan Karakteristik Pegawai Pemerintah Daerah dan Implementasi Sistem Pengukuran Kinerja: Perspektif Isomorfisma Institusional. Jurnal Akuntansi dan Auditing Indonesia (JAAI). 19 (2), 153-173.

Sofyani, H. and R. Akbar. 2013. Hubungan Faktor Internal Institusi dan Implementasi Sistem Akuntabilitas Kinerja Instansi Pemerintah (SAKIP) di Pemerintah Daerah. Jurnal Akuntansi dan Keuangan Indonesia (JAKI). 10 (2), 184-205.

Syachbrani, W. and R. Akbar. 2013. Faktor-faktor Teknis dan Keorganisasian yang Mempengaruhi Pengembangan Sistem Pengukuran Kinerja Pemerintah Daerah. Jurnal Reviu Akuntansi (JRAK). 3 (2), 447-463.

Talbot, C. 2008. Performance Regimes - The Institutional Context of Performance Policies. International Journal of Public Administration, 31 (14), 1569-1591.

Wijaya, A. C. and R. Akbar. 2013. The Influence of Information, Organizational Objectives and Targets, and External Pressure Towards the Adoption of Performance Measurement System in Public Sector. Journal of Indonesian Economy and Business. 28 (1), 62-83. 